\title{
SISTEM KELISTRIKAN PADA KAPAL PERANG TNI AL KELAS FROSCH KRI TELUK CELUKAN BAWANG 532
}

\author{
Rinna Hariyati ${ }^{1)}$, Sigit Sukmajati ${ }^{2}$, Rido Dwilingga ${ }^{3)}$ \\ Teknik Elektro, Sekolah Tinggi Teknik - PLN \\ ${ }^{1}$ rinna.hariyati@gmail.com, \\ 2sigitsukmajati@yahoo.com \\ 3ridodwilingga@gmail.com
}

\begin{abstract}
A warship has its own power plant which directly supply and distribute to meet its electrical power demand. On a warship which operated by Satuan Amphibi Komando Armada Republik Indonesia Kawasan Barat TNI AL, KRI Teluk Celukan Bawang 532 has 4 diesel generators located in engine room. This 4 diesel generators have a parallel connection and alternately work with the change of electrical load. The change of electric load based on a warship operating conditions. Power supply on the warship needs to generate and maintain a constant electric voltage and frequency, as well as a sufficient power when a warship is docking, before sailing and sailing. A calculation of elecric loads is very important to choose the capacity and the number of generator used with limited space on a warship.
\end{abstract}

Keywords: Warship Electrical System, KRI Teluk Celukan Bawang 532, TNI AL's Warship

\begin{abstract}
Abstrak : Suatu kapal perang memiliki unit pembangkit listrik dan sistem distribusi yang menyuplai langsung kebutuhan listrik di kapal. Pada kapal perang yang dioperasikan oleh Satuan Amphibi Komando Armada Republik Indonesia Kawasan Barat TNI AL, KRI Teluk Celukan Bawang 532 memiliki unit pembangkit yang terdiri dari 4 buah diesel generator yang terletak pada kamar mesin (engine room). 4 buah generator ini terhubung paralel dan bekerja secara bergantian dengan beban listrik yang berubah. Perubahan beban listrik pada kapal berdasarkan pada kondisi operasi kapal. Pembangkit listrik pada kapal harus dapat menghasilkan tegangan dan frekuensi konstan serta daya yang cukup untuk menyuplai seluruh kebutuhan listrik pada kapal baik dalam kondisi sandar, persiapan berlayar dan berlayar. Perhitungan beban listrik sangat menentukan pemilihan kapasitas dan jumlah generator yang digunakan dengan ruangan yang terbatas pada kapal
\end{abstract}

Kata Kunci : Sistem Kelistrikan Kapal Perang, KRI Teluk Celukan Bawang 532, Kapal Perang TNI AL

\section{PENDAHULUAN}

Kapal perang adalah kapal yang digunakan untuk kepentingan pertahanan dan keamanan laut.

Salah satu armada pendukung yang dimiliki TNI AL adalah KRI Teluk Celukan Bawang 532 yang merupakan kapal perang kelas Frosch. KRI Teluk Celukan Bawang 532 berperan sebagai kapal angkut personil dan kendaraan tempur diantaranya Tank, Tank Amfibi, dan Panser.

Maka dalam penelitian ini penulis tertarik untuk melakukan penelitian sistem kelistrikan pada KRI Teluk Celukan
Bawang 532 untuk dijadikan bahan pembelajaran dalam perencanaan pembuatan kapal perang.

\section{LANDASAN TEORI}

Sistem tenaga pada kapal perang adalah sistem yang menunjang operasi kapal perang. Sistem tenaga pada kapal perang terdiri dari 2 sistem tenaga yaitu sistem tenaga penggerak kapal dan sistem tenaga listrik kapal. Saat ini sistem tenaga pada kapal ditunjang oleh mesin diesel yaitu mesin utama/mesin pokok dan mesin bantu. 


\subsection{Sistem Tenaga Penggerak Kapal Perang \\ Pada KRI Teluk Celukan Bawang} 532, sistem tenaga penggerak kapal ditunjang oleh 2 buah mesin diesel/mesin utama (Main Propulsion Engine) yang masing-masing mesin terhubung langsung dengan Propeller / baling-baling kapal. Mesin utama dan mesin bantu pada kapal terletak secara terpisah. Mesin utama pada kapal perang bekerja ketika kapal dalam kondisi persiapan berlayar, berlayar, dan berlabuh, sementara mesin bantu untuk menghasilkan tenaga listrik bekerja setiap saat baik saat kapal berlayar maupun saat kapal sandar.

\subsection{Sistem Tenaga Listrik Kapal Perang}

Biro Klasifikasi Indonesia (BKI) Vol. IV tahun 2016 mensyaratkan bahwa sekurang-kurangnya 2 agregat yang terpisah dari mesin penggerak utama harus disediakan untuk pemberi daya listrik. Daya keluaran harus berukuran sedemikian sehingga keluaran generator masih tersisa dan cukup untuk memenuhi kebutuhan daya listrik dalam pelayaran di laut ketika salah satu agregat rusak ataupun dihentikan.

Menurut peraturan BKI Vol. IV tahun 2016 tegangan rendah pada kapal berkisar antara $50 \mathrm{~V}-17,5 \mathrm{kV}$. Tegangan rendah yang saat ini digunakan pada sistem kelistrikan kapal perang terdiri dari 2 sistem tegangan rendah yaitu tegangan 440 V $60 \mathrm{~Hz}$ dan 380 V $50 \mathrm{~Hz}$.

Salah satu sistem tenaga listrik pada kapal perang yang menggunakan tegangan rendah $380 \mathrm{~V} 50 \mathrm{~Hz}$ seperti yang terlihat pada gambar 2.15

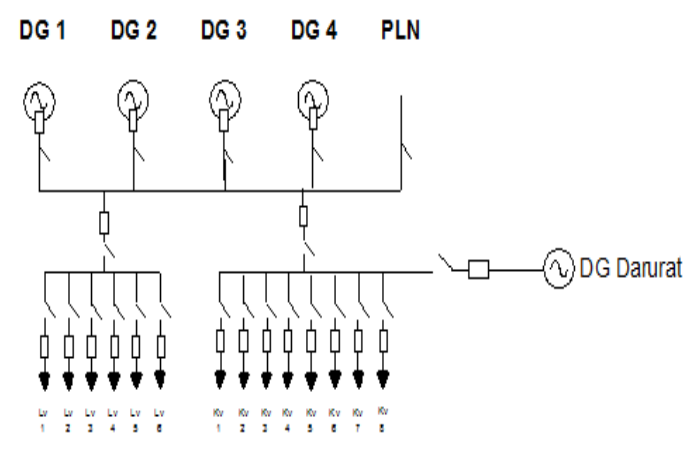

Gambar 2.15 Diagram satu garis sistem tenaga listrik KRI Teluk Celukan Bawang 532.

\subsection{Sistem Suplai Tenaga Listrik Pada Kapal Perang \\ KRI Teluk Celukan Bawang 532} memiliki sistem suplai tenaga listrik yang terdiri dari 4 unit diesel generator adalah seperti yang terlihat pada gambar 2.16

Sistem suplai tenaga listrik pada kapal perang dibagi menjadi :

1. Pembangkit Listrik Utama

Seperti yang terlihat pada gambar 2.16 seluruh peralatan pembangkit listrik utama terletak pada ruang mesin (engine room) diesel generator pada kapal.

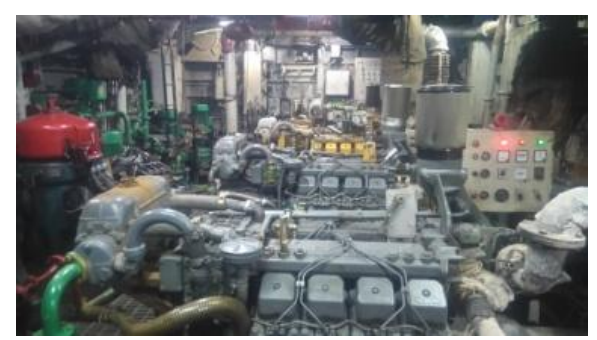

Gambar 2.16 ruang mesin diesel generator KRI Teluk Celukan Bawang 532

Pembangkit listrik utama pada kapal perang terdiri dari :

a. Mesin Diesel

Mesin diesel pembangkit listrik utama pada kapal merupakan mesin bantu (auxiliary engine) yang terpisah dari mesin utama penggerak kapal

KRI Teluk Celukan Bawang 532 memiliki 4 unit mesin diesel (mesin bantu) yang bekerja secara pararel dan bergantian.

b. Generator

KRI Teluk Celukan Bawang 532 memiliki 4 unit alternator 3 fasa yang masing-masing alternator terhubung langsung dengan mesin diesel. 1 unit alternator memiliki kapasitas 338 kVA dengan tegangan keluaran $400 \mathrm{~V}$ dan frekuensi tegangan keluaran $50 \mathrm{~Hz}$.

Selain generator 3 fasa $400 \vee 50 \mathrm{~Hz}$, beberapa kapal perang TNI AL juga menggunakan generator 3 fasa $460 \mathrm{~V}$ $60 \mathrm{~Hz}$ dengan pertimbangan pemilihan tegangan dan frekuensi keluaran generator berdasarkan karakteristik beban listrik pada kapal.

c. Sistem Kontrol

Sistem kontrol pada pembangkit listrik kapal berfungsi sebagai sistem yang mengatur kerja mesin diesel (mesin 
bantu) agar generator menghasilkan tegangan dan frekuensi konstan. Selain mengatur tegangan dan frekuensi, sistem kontrol pada sistem pembangkit listrik juga mengatur aliran daya yang di hasilkan generator yang bekerja secara paralel dan bergantian.

1) Pengatur Tegangan Otomatis

2) Governor

3) Saklar Pemindah Otomatis

4) Modul Kontrol Generator

\section{Pembangkit Listrik Darurat}

Pembangkit listrik darurat harus terdapat pada sistem suplai tenaga listrik pada kapal perang sebagai sistem cadangan manakala pembangkit listrik utama mengalami gangguan sehingga tidak dapat menghasilkan energi listrik. Pembangkit listrik utama yang terletak pada ruang mesin (engine room) memiliki resiko terendam air lebih dahulu sehingga letak pembangkit listrik darurat berada pada bagian haluan kapal.

3. Listrik Aliran Darat

Listrik aliran darat adalah istilah yang digunakan oleh TNI AL untuk menyebut aliran listrik dari PT. PLN (Persero) yang menyuplai listrik ke kapal di dermaga pangkalan TNI AL. Pada saat kapal sandar, kebutuhan listrik pada kapal antara lain penerangan, penyejuk udara, pompa-pompa dan keperluan dapur dapat di suplai dari tenaga listrik aliran darat dengan tujuan penghematan biaya.

\subsection{Sistem Distribusi Listrik Pada Kapal Perang}

Sistem distribusi listrik pada kapal perang terpusat pada panel utama / MSB (Main Switch Board). Sistem distribusi arus bolak-balik pada KRI Teluk Celukan Bawang 532 dibagi menjadi 2 yaitu distribusi 3 fasa dan distribusi 1 fasa seperti yang terlihat pada gambar 2.15

Menurut peraturan Biro Klasifikasi Indonesia (BKI) Vol. IV tahun 2016 bahwa sistem distribusi listrik baik tegangan bolak-balik 3 fasa dan 1 fasa maupun distribusi listrik tegangan searah, kawat penghantar netral dapat menggunakan badan / lambung kapal (Hull Return) kecuali pada kapal tanker dan kapal dengan Gross Tonage (GT) diatas 1600.

\subsection{Sistem Proteksi Listrik Pada Kapal Perang}

Sistem proteksi pada kapal perang terletak pada panel utama dan panel lokal yang menjadi panel pembagi arus dan pemutus atau penyambung beban. Sistem inslatasi listrik pada kapal dilengkapi dengan sistem proteksi listrik yang berfungsi untuk mengamankan peralatan listrik dari arus lebih baik dari gangguan maupun kesalahan pada sistem kelistrikan kapal. Peralatan sistem proteksi pada kapal perang terdiri dari :

1. Circuit Breaker

Pada KRI Teluk Celukan Bawang 532 MCCB di pasang pada panel utama (Main Switch Board), sedangkan MCB dipasang pada panel lokal yang juga menjadi saklar pemutus atau penyambung beban.

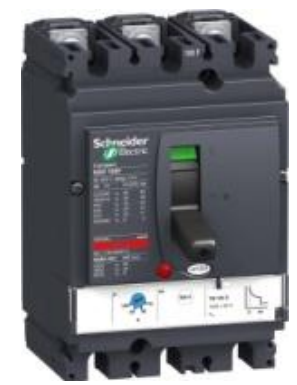

Gambar 2.19 Molded Case Circuit Breaker

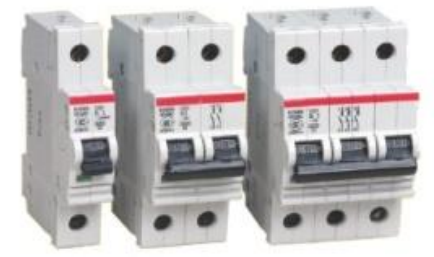

Gambar 2.20 Mini Circuit Breaker

2. Fuse (sekering)

Pada KRI Teluk Celukan Bawang 532, fuse yang digunakan untuk mengamankan motor listrik 3 fasa merupakan fuse dengan tipe DII Diazed Fuse seperti yang terlihat pada gambar 2.19 .

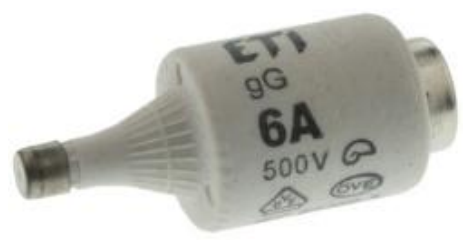

Gambar 2.21 DII Diazed Fuse 


\section{METODE PENELITIAN}

\subsection{Metodologi Perencanaan Sistem Suplai Tenaga Listrik Pada Kapal Perang}

Prosedur perencanaan merupakan proses atau langkah-langkah yang bertujuan agar perencanaan dapat dilakukan secara sistematis, efisien dan efektif. Metode perencanaan dapat dibuat seperti pada gambar 3.1 yang menunjukkan proses perencanaan sistem kelistrikan kapal perang.

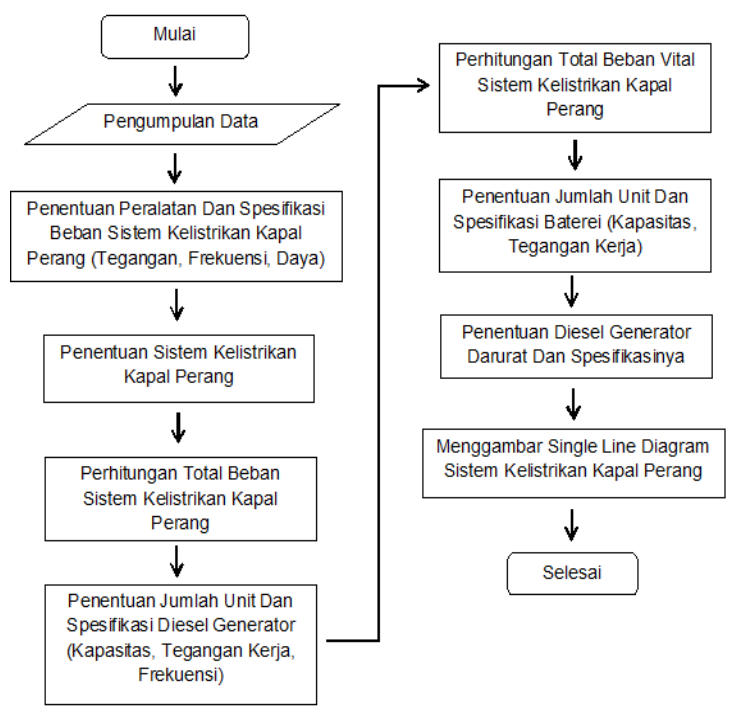

Gambar 3.1 Diagram alir perencanaan sistem suplai tenaga listrik kapal perang

\subsection{Penentuan Peralatan dan Spesifikasi Beban Listrik Kapal Perang}

Menentukan peralatan dan spesifikas beban listrik pada kapal perang bergantung pada :

1. Klasifikasi kapal perang

Klasifikasi kapal perang tertentu memiliki spesifikasi beban listrik yang berbeda dengan klasifikasi kapal perang yang lain seperti pada penggunaan meriam, peluncur torpedo, sonar, crane, dan lain sebagainya.

2. Desain dan Ukuran kapal perang Desain dan Ukuran dari sebuah kapal perang (panjang, lebar, tinggi, daya muat, jumlah dek, jumlah ruangan) menentukan spesifikasi dan jumlah peralatan listrik yang digunakan pada kapal seperti sistem penerangan, penyejuk udara, keperluan dapur, pompa air laut, pompa air tawar, pompa bahan bakar, dan lain sebagainya.

\subsection{Penentuan Sistem Kelistrikan Kapal Perang}

Sistem kelistrikan pada kapal perang menggunakan distribusi tegangan rendah (50 V - 17,5 kV). Sistem kelistrikan tegangan rendah (Phase Voltage) di dunia berbeda - beda antara lain $220 \mathrm{~V} 50 \mathrm{~Hz}$ di Indonesia, 220 V $60 \mathrm{~Hz}$ di Korea, $120 \mathrm{~V}$ $50 \mathrm{~Hz}$ di Jepang, dan $120 \mathrm{~V} 60 \mathrm{~Hz}$ di Amerika Utara. KRI Teluk Celukan Bawang 532 buatan Jerman menggunakan sistem kelistrikan $380 \mathrm{~V} 50$ $\mathrm{Hz}$ (Line Voltage) dan 220 V $50 \mathrm{~Hz}$ (Phase Voltage) seperti pada sistem kelistrikan negara Jerman.

\subsection{Perencanaan Sistem Pembangkit Listrik Pada Kapal Perang}

Merencanakan sistem pembangkit listrik pada kapal perang maka perlu menghitung total beban listrik minimum dan maksimum. Kondisi operasional kapal terdiri dari :

1. Sandar

2. Persiapan berlayar

3. Berlayar

\subsubsection{Penentuan Kapasitas Generator Utama}

Menentukan kapasitas generator utama pada kapal perang berdasarkan beban minimum dan beban maksimum dapat menggunakan rumus :

$$
S=\frac{P}{\text { eff } \mathrm{x} \cos \varphi}
$$

Dimana :

$$
\begin{array}{ll}
\mathrm{S} & =\text { Daya Semu }(\mathrm{kVA}) \\
\mathrm{P} & =\text { Daya Aktif }(\mathrm{kW}) \\
\text { Cos } \varphi & =\text { Faktor Daya } \\
\text { eff } & =\text { Efisiensi Motor }(\%)
\end{array}
$$

Rumus tersebut diatas untuk menghitung beban listrik berupa motor-motor listrik. Sedangkan untuk menghitung kVA beban non motor dapat menggunakan rumus :

$$
S=\frac{P}{\cos \varphi}
$$


Dimana :

$$
\begin{array}{ll}
\mathrm{S} & =\text { Daya semu }(\mathrm{kVA}) \\
\mathrm{P} & =\text { Daya aktif }(\mathrm{kW}) \\
\cos \varphi & =\text { faktor daya }
\end{array}
$$

Setelah mengetahui total kebutuhan daya yang merupakan kapasitas beban pada kapal perang, maka kapasitas generator dapat dihitung dengan menggunakan rumus:

Kapasitas Generator $=$

Fd $x$ Kapasitas Beban

Dimana :

Kapasitas Generator = Daya yang

ditanggung generator (kVA)

$\mathrm{Fd}=$ Diversity Factor (faktor

kesamarataan)

Kapasitas Beban $=$ Total beban $(\mathrm{kVA})$

Sesuai dengan peraturan Biro Klasifikasi Indonesia Vol. IV tahun 2016 bahwa generator utama memiliki jumlah sekurang-kurangnya 2 unit sehingga dalam merencanakan generator utama pada kapal perang harus dilebihkan 1 unit.

\subsubsection{Penentuan Jumlah Dan Spesifikasi Baterai}

Untuk menentukan kapasitas baterei yang digunakan sebagai pembangkit listrik darurat dapat menggunakan rumus : Kapasitas Baterei $=$ I $x$ Lama Waktu

Dimana :

Kapasitas Baterei $=$ Kapasitas Baterei $(\mathrm{Ah})$

I = Arus Beban Listrik (Amp)

Lama waktu = Lama Waktu Keadaan

Darurat (jam)

\subsubsection{Penentuan Kapasitas Generator Darurat}

Karena sifat dari Baterei yang dapat menyuplai energi listrik hanya sementara (1 Jam), maka menentukan kapasitas generator darurat perlu diperhitungkan untuk suplai beban-beban yang termasuk dalam kategori beban vital / penting yang tidak boleh mati (Shutdown) baik dalam keadaan normal maupun keadaan darurat.

\section{HASIL DAN PEMBAHASAN}

\subsection{Data Teknis}

\begin{tabular}{|c|c|c|}
\hline $\begin{array}{l}\text { Nama Kapal - } \\
\text { Nomor Lambung }\end{array}$ & : & $\begin{array}{l}\text { KRI Teluk Celukan } \\
\text { Bawang - } 532\end{array}$ \\
\hline Kelas & : & $\begin{array}{l}\text { Frosch/Landing } \\
\text { Ship Tank }\end{array}$ \\
\hline Negara Pembuat & : & $\begin{array}{l}\text { Deutsche } \\
\text { Demokratische } \\
\text { Republik / Jerman } \\
\text { Timur }\end{array}$ \\
\hline $\begin{array}{l}\text { Tahun } \\
\text { Pembuatan }\end{array}$ & : & 1976 \\
\hline $\begin{array}{l}\text { Pabrik / } \\
\text { Galangan }\end{array}$ & : & $\begin{array}{l}\text { VEB Penee Werft } \\
\text { Wolgast }\end{array}$ \\
\hline Panjang Maks & : & $90,78 \mathrm{M}$ \\
\hline $\begin{array}{l}\text { Panjang Garis } \\
\text { Tegak }\end{array}$ & : & $80,35 \mathrm{M}$ \\
\hline Panjang Garis Air & : & $82,50 \mathrm{M}$ \\
\hline Lebar Maks & : & $11,12 \mathrm{M}$ \\
\hline $\begin{array}{l}\text { Lebar Pada Garis } \\
\text { Air }\end{array}$ & : & $10,80 \mathrm{M}$ \\
\hline Tinggi Maks & : & $28 \mathrm{M}$ \\
\hline $\begin{array}{l}\text { Tinggi Muatan } \\
\text { Maks (Draft) }\end{array}$ & : & $3,2 \mathrm{M}$ \\
\hline $\begin{array}{l}\text { Berat Kosong } \\
(\text { Netto })\end{array}$ & : & 1.283 Ton \\
\hline $\begin{array}{l}\text { Berat Muatan } \\
\text { Penuh (Gross) }\end{array}$ & : & 1.936 Ton \\
\hline $\begin{array}{l}\text { Pendorong } \\
\text { Pokok }\end{array}$ & : & $\begin{array}{l}\text { Mesin Diesel } 6.000 \\
\text { BHP }\end{array}$ \\
\hline $\begin{array}{l}\text { Jumlah } \\
\text { Pendorong } \\
\text { Pokok }\end{array}$ & : & 2 Unit \\
\hline Jumlah Propeller & : & 2 Unit \\
\hline $\begin{array}{l}\text { Kecepatan } \\
\text { Ekonomis }\end{array}$ & : & 14 Knots \\
\hline Kecepatan Maks & : & 18 Knots \\
\hline
\end{tabular}

Berikut ini adalah data teknis $\mathrm{KRI}$ Teluk Celukan Bawang 532.

Data-data peralatan dan beban listrik yang diperlukan untuk merencanakan sistem kelistrikan KRI Teluk Celukan Bawang 532 adalah sebagai berikut :

1. Data peralatan dan beban listrik sistem komunikasi dan navigasi.

2. Data peralatan dan beban listrik sistem pemompaan.

3. Data peralatan dan beban listrik sistem pendingin dan sirkulasi udara. 
4. Data peralatan dan beban listrik sistem penerangan.

5. Data peralatan dan beban listrik peralatan bantu.

\subsubsection{Data Peralatan Sistem Navigasi dan Komunikasi}

Peralatan sistem navigasi dan komunikasi KRI Teluk Celukan Bawang 532 dikelompokkan sebagai berikut:

\section{Peralatan Navigasi}

Tabel 4.1 Peralatan Navigasi

\begin{tabular}{|l|l|l|l|l|l|}
\hline \multirow{2}{*}{ No } & \multirow{2}{*}{ Description } & \multicolumn{3}{|l|}{ Rating } \\
\cline { 3 - 6 } & Watt & $\begin{array}{l}\text { Vs } \\
\text { AC }\end{array}$ & PF & $\begin{array}{l}\text { Vs } \\
\text { DC }\end{array}$ \\
\hline 1 & $\begin{array}{l}\text { Gyro } \\
\text { Compass }\end{array}$ & 1200 & 380 & 0.80 & 84 \\
\hline 2 & $\begin{array}{l}\text { Magnet } \\
\text { Compass }\end{array}$ & 65 & 220 & 0.80 & 24 \\
\hline 3 & Speed Log & 750 & 220 & 0.80 & 84 \\
\hline 4 & $\begin{array}{l}\text { General } \\
\text { Positioning } \\
\text { System }\end{array}$ & 100 & 220 & 0.80 & 24 \\
\hline 5 & $\begin{array}{l}\text { Navigation } \\
\text { Control } \\
\text { Board }\end{array}$ & 1000 & 220 & 0.80 & 24 \\
\hline 6 & RFT Radar & 600 & 220 & 0.80 & 84 \\
\hline
\end{tabular}

\section{Peralatan Komunikasi}

Tabel 4.2 Peralatan Komunikasi

\begin{tabular}{|l|l|l|l|l|l|}
\hline No & Description & \multicolumn{4}{|l|}{ Rating } \\
\cline { 2 - 6 } & Watt & $\begin{array}{l}\text { Vs } \\
\text { AC }\end{array}$ & PF & $\begin{array}{l}\text { Vs } \\
\text { DC }\end{array}$ \\
\hline 1 & $\begin{array}{l}\text { HF } \\
\text { Tranceiver } \\
\text { \& Receiver }\end{array}$ & 200 & 220 & 0.80 & 24 \\
\hline 2 & $\begin{array}{l}\text { VHF } \\
\text { Tranceiver } \\
\text { \& Receiver }\end{array}$ & 300 & 220 & 0.80 & 24 \\
\hline 3 & $\begin{array}{l}\text { Handy } \\
\text { Talkie }\end{array}$ & 100 & 220 & 0.80 & - \\
\hline 4 & Horn & 280 & 220 & 0.80 & - \\
\hline 5 & Alarm & 240 & 220 & 0.80 & - \\
\hline 6 & $\begin{array}{l}\text { Loud } \\
\text { Speaker }\end{array}$ & 200 & 220 & 0.80 & - \\
\hline
\end{tabular}

\subsubsection{Data Peralatan Sistem Pemompaan}

Peralatan sistem pemompaan $\mathrm{KRI}$ Teluk Cirebon 532 dikelompokan sebagai berikut :

\section{Pompa Bahan Bakar}

Tabel 4.3 Peralatan Pompa Bahan Bakar

\begin{tabular}{|l|l|l|l|l|l|l|}
\hline \multirow{2}{*}{ No } & Description & Qty & \multicolumn{3}{|l|}{ Rating } \\
\cline { 3 - 6 } 1 & $\mathrm{~kW}$ & eff & PF & Vs \\
\hline & $\begin{array}{l}\text { Fuel Oil } \\
\text { Priming } \\
\text { Pump (Main } \\
\text { Engine) }\end{array}$ & 1 & 0.7 & 0.80 & 0.70 & 380 \\
\hline 2 & $\begin{array}{l}\text { Fuel Oil } \\
\text { Transfer } \\
\text { Pump }\end{array}$ & 2 & 7.1 & 0.80 & 0.81 & 380 \\
\hline 3 & $\begin{array}{l}\text { Fuel Oil } \\
\text { Separating } \\
\text { Pump }\end{array}$ & 2 & 7.1 & 0.80 & 0.81 & 380 \\
\hline 4 & $\begin{array}{l}\text { Fuel Oil } \\
\text { Draining } \\
\text { Pump }\end{array}$ & 1 & 0.52 & 0.80 & 0.81 & 380 \\
\hline
\end{tabular}

\section{Pompa Minyak Lincir}

Tabel 4.4 Peralatan Pompa Minyak Linci

\begin{tabular}{|l|l|l|l|l|l|l|}
\hline \multirow{2}{*}{ No } & \multirow{2}{*}{ Description } & \multirow{2}{*}{ Qty } & \multicolumn{4}{|l|}{ Rating } \\
\cline { 4 - 7 } & & $\mathrm{kW}$ & $\mathrm{Eff}$ & $\mathrm{PF}$ & $\mathrm{Vs}$ \\
\hline 1 & $\begin{array}{l}\text { Lube Oil } \\
\text { Transfer Pump }\end{array}$ & 2 & 1 & 0.80 & 0.81 & 380 \\
\hline 2 & $\begin{array}{l}\text { Lube Oil } \\
\text { Cooling Pump } \\
\text { (Main Engine) }\end{array}$ & 2 & 14.5 & 0.80 & 0.8 & 380 \\
\hline 3 & $\begin{array}{l}\text { Lube Oil } \\
\text { Separating } \\
\text { Pump }\end{array}$ & 2 & 7.1 & 0.80 & 0.81 & 380 \\
\hline 4 & $\begin{array}{l}\text { Lube Oil } \\
\text { Draining Pump }\end{array}$ & 1 & 1 & 0.80 & 0.81 & 380 \\
\hline 5 & $\begin{array}{l}\text { Lube Oil } \\
\text { Cooling Pump } \\
\text { (Thrust } \\
\text { Bearing) }\end{array}$ & 2 & 1.1 & 0.80 & 0.80 & 380 \\
\hline 6 & $\begin{array}{l}\text { Lube Oil } \\
\text { Suction Pump } \\
\text { (Main Engine) }\end{array}$ & 2 & 14.5 & 0.90 & 0.80 & 380 \\
\hline
\end{tabular}

\section{Pompa Air Laut}

Tabel 4.5 Peralatan Pompa Air Laut

\begin{tabular}{|l|l|l|l|l|l|l|}
\hline \multirow{2}{*}{ No } & Description & Qty & \multicolumn{4}{|c|}{ Rating } \\
\cline { 4 - 7 } 1 & $\mathrm{~kW}$ & $\mathrm{Eff}$ & $\mathrm{PF}$ & $\mathrm{Vs}$ \\
\hline & $\begin{array}{l}\text { Sea Water } \\
\text { Cooling } \\
\text { Pump (Aux } \\
\text { Engine) }\end{array}$ & 2 & 2.05 & 0.80 & 0.80 & 380 \\
\hline 2 & $\begin{array}{l}\text { Sea Water } \\
\text { Sanitation } \\
\text { Pump }\end{array}$ & 1 & 2.05 & 0.80 & 0.80 & 380 \\
\hline 3 & $\begin{array}{l}\text { Leak Pump / } \\
\text { Ballast } \\
\text { Pump }\end{array}$ & 2 & 35 & 0.80 & 0.87 & 380 \\
\hline 4 & $\begin{array}{l}\text { Engine } \\
\text { Room Bilge } \\
\text { Pump }\end{array}$ & 1 & 0.35 & 0.80 & 0.80 & 380 \\
\hline
\end{tabular}




\section{Pompa Air Tawar}

Table 4.6 Peralatan Pompa Air Tawar

\begin{tabular}{|c|c|c|c|c|c|c|}
\hline \multirow{2}{*}{ No } & \multirow{2}{*}{ Description } & \multirow{2}{*}{ Qty } & \multicolumn{4}{|c|}{ Rating } \\
\hline & & & $\mathrm{kW}$ & eff & PF & Vs \\
\hline 1 & $\begin{array}{l}\text { Fresh Water } \\
\text { Circulating } \\
\text { Pump }\end{array}$ & 2 & 2.05 & 0.80 & 0.80 & 380 \\
\hline 2 & $\begin{array}{l}\text { Fresh Water } \\
\text { Transfer } \\
\text { Pump }\end{array}$ & 1 & 2.05 & 0.80 & 0.80 & 380 \\
\hline 3 & $\begin{array}{l}\text { Fresh Water } \\
\text { Cooling } \\
\text { Pump (Main } \\
\text { Engine) }\end{array}$ & 2 & 35 & 0.80 & 0.80 & 380 \\
\hline 4 & $\begin{array}{l}\text { Fresh Water } \\
\text { Cooling } \\
\text { Pump (Aux } \\
\text { Engine) }\end{array}$ & 1 & 0.11 & 0.80 & 0.80 & 380 \\
\hline 5 & $\begin{array}{l}\text { Fresh Water } \\
\text { Expansion } \\
\text { Tank Pump } \\
\text { (Main \& Aux } \\
\text { Engine) }\end{array}$ & 1 & 0.25 & 0.80 & 0.75 & 380 \\
\hline
\end{tabular}

\section{Pompa Air Kotor}

Tabel 4.7 Peralatan Pompa Air Kotor

\begin{tabular}{|l|l|l|l|l|l|l|}
\hline \multirow{2}{*}{ No } & \multirow{2}{*}{ Description } & \multirow{2}{*}{ Qty } & \multicolumn{4}{|c|}{ Rating } \\
\cline { 4 - 7 } 1 & $\begin{array}{l}\text { Sewage } \\
\text { Separator } \\
\text { Pump }\end{array}$ & 1 & 0.35 & 0.80 & 0.8 & 380 \\
\hline 2 & $\begin{array}{l}\text { Sewage } \\
\text { Draining } \\
\text { Pump }\end{array}$ & 1 & 3.8 & 0.80 & 0.8 & 380 \\
\hline
\end{tabular}

\subsubsection{Data Peralatan Sistem}

Penerangan

Sistem penerangan pada KRI Teluk Celukan Bawang 532 dikelompokan sebagai berikut :

\section{Peralatan Penerangan Luar}

Tabel 4.8 Peralatan Penerangan Luar

\begin{tabular}{|l|l|l|l|l|l|}
\hline \multirow{2}{*}{ No } & \multirow{2}{*}{ Description } & \multirow{2}{*}{ Qty } & \multicolumn{3}{|l|}{ Rating } \\
\cline { 4 - 6 } & & Watt & PF & Vs \\
\hline 1 & Head Master Light & 2 & 1000 & 0.80 & 220 \\
\hline 2 & Side Light & 2 & 300 & 0.80 & 220 \\
\hline 3 & Anchor Light & 2 & 150 & 0.80 & 220 \\
\hline 4 & Stern Light & 1 & 100 & 0.80 & 220 \\
\hline 5 & $\begin{array}{l}\text { Morse Signal } \\
\text { Light }\end{array}$ & 1 & 500 & 0.80 & 220 \\
\hline
\end{tabular}

\section{Peralatan Penerangan Dalam}

Tabel 4.9 Peralatan Penerangan Dalam

\begin{tabular}{|l|l|l|l|l|l|}
\hline \multirow{2}{*}{ No } & \multirow{2}{*}{ Description } & Qty & \multicolumn{3}{|l|}{ Rating } \\
\cline { 4 - 6 } & & Watt & PF & Vs \\
\hline 1 & $\begin{array}{l}\text { Fluorescent } \\
\text { Lamp }\end{array}$ & 175 & 20 & 0.80 & 220 \\
\hline 2 & $\begin{array}{l}\text { Emergency } \\
\text { Lamp }\end{array}$ & 170 & 15 & - & 220 \\
\hline
\end{tabular}

\subsubsection{Data Peralatan Sistem Pendingin dan Sirkulasi Udara}

Peralatan sistem pendingin dan sirkulasi udara KRI Teluk Cirebon 532 dikelompokan sebagai berikut:

\section{Peralatan Pendingin Khusus}

Tabel 4.10 Peralatan Pendingin Khusus

\begin{tabular}{|l|l|l|l|l|l|l|}
\hline \multirow{2}{*}{ No } & \multirow{2}{*}{ Description } & Qty & \multicolumn{4}{|c|}{ Rating } \\
\cline { 4 - 7 } 1 & $\begin{array}{l}\text { Water } \\
\text { Chiller } \\
\text { Cooling } \\
\text { Pump }\end{array}$ & 2 & 7.5 & 0.80 & 0.8 & 380 \\
\hline 2 & $\begin{array}{l}\text { Weapon } \\
\text { Cooling } \\
\text { Pump }\end{array}$ & 2 & 21 & 0.80 & 0.8 & 380 \\
\hline
\end{tabular}

\section{Peralatan Ruangan Pendingin}

\section{(Fresh Room)}

Tabel 4.11 Peralatan Ruangan Pendingin

\begin{tabular}{|l|l|l|l|l|l|l|}
\hline \multirow{2}{*}{ No } & \multirow{2}{*}{ Description } & Qty & \multicolumn{4}{|c|}{ Rating } \\
\cline { 3 - 6 } 1 & $\begin{array}{l}\text { Fresh } \\
\begin{array}{l}\text { Room } \\
\text { Condenser }\end{array}\end{array}$ & 1 & 7.5 & - & 0.8 & 380 \\
\hline 2 & $\begin{array}{l}\text { Condenser } \\
\text { Cooling } \\
\text { Pump }\end{array}$ & 1 & 1.1 & 0.8 & 0.8 & 380 \\
\hline
\end{tabular}

\section{Peralatan Sirkulasi Udara (Blower)}

Tabel 4.12 Peralatan Sirkulasi Udara

\begin{tabular}{|l|l|l|l|l|l|l|}
\hline \multirow{2}{*}{ No } & Description & Qty & \multicolumn{4}{|l|}{ Rating } \\
\cline { 4 - 7 } & & $\mathrm{kW}$ & eff & PF & Vs \\
\hline 1 & $\begin{array}{l}\text { Air Circulating } \\
\text { Blower }\end{array}$ & 13 & 0.52 & 0.80 & 0.85 & 380 \\
\hline 2 & $\begin{array}{l}\text { Air Circulating } \\
\text { Blower (Main } \\
\text { Eng Room) }\end{array}$ & 2 & 3.3 & 0.80 & 0.80 & 380 \\
\hline 3 & $\begin{array}{l}\text { Air Circulating } \\
\text { Blower (Aux } \\
\text { Eng Room) }\end{array}$ & 2 & 3.3 & 0.80 & 0.80 & 380 \\
\hline
\end{tabular}




\section{Peralatan Pendingin Ruangan}

Tabel 4.13 Peralatan Pendingin Ruagan

\begin{tabular}{|l|l|l|l|l|l|l|}
\hline \multirow{2}{*}{ No } & \multirow{2}{*}{ Description } & \multirow{2}{*}{ Qty } & \multicolumn{4}{|c|}{ Rating } \\
\cline { 4 - 7 } & & & $\mathrm{kW}$ & eff & PF & Vs \\
\hline 1 & Air Conditioner & 2 & 52 & - & 0.8 & 380 \\
\hline 2 & Fan Coil Room 1 & 7 & 0.09 & 0.8 & 0.8 & 220 \\
\hline 3 & Fan Coil Room 2 & 2 & 0.09 & 0.8 & 0.8 & 220 \\
\hline 4 & Fan Coil Room 3 & 5 & 0.09 & 0.8 & 0.8 & 220 \\
\hline 5 & Fan Coil Room 4 & 5 & 0.09 & 0.8 & 0.8 & 220 \\
\hline 6 & Fan Coil Room 5 & 19 & 0.09 & 0.8 & 0.8 & 220 \\
\hline
\end{tabular}

\subsubsection{Data Peralatan Bantu}

Peralatan Bantu KRI Teluk Celukan Bawang 532 dikelompokan sebagai berikut :

\section{Peralatan Khusus}

Tabel 4.14 Peralatan Khusus

\begin{tabular}{|c|c|c|c|c|c|c|}
\hline \multirow{2}{*}{ No } & \multirow{2}{*}{ Description } & \multirow{2}{*}{ Qty } & \multicolumn{4}{|c|}{ Rating } \\
\hline & & & $\mathrm{kW}$ & eff & PF & Vs \\
\hline 1 & $\begin{array}{l}\text { Hydraulic } \\
\text { Pump (Steering } \\
\text { Gear) }\end{array}$ & 2 & 5.3 & 0.80 & 0.80 & 380 \\
\hline 2 & $\begin{array}{l}\text { Ramp } \\
\text { Hydraulic } \\
\text { Pump }\end{array}$ & 1 & 37 & 0.80 & 0.80 & 380 \\
\hline 3 & $\begin{array}{l}\text { Track Ramp } \\
\text { Hydraulic } \\
\text { Pump }\end{array}$ & 1 & 15 & 0.80 & 0.85 & 380 \\
\hline 4 & $\begin{array}{l}\text { Bower Anchor } \\
\text { Windlass }\end{array}$ & 2 & 38 & 0.80 & 0.80 & 380 \\
\hline 5 & $\begin{array}{l}\text { Stern Anchor } \\
\text { Windlass }\end{array}$ & 1 & 11.8 & 0.80 & 0.80 & 380 \\
\hline 6 & $\begin{array}{l}\text { Fresh Water } \\
\text { PreHeater } \\
\text { (Main Engine) }\end{array}$ & 3 & 1.2 & - & 0.80 & 220 \\
\hline 7 & $\begin{array}{l}\text { Lube Oil } \\
\text { PreHeater } \\
\text { (Main Engine) }\end{array}$ & 2 & 30 & - & 0.80 & 380 \\
\hline 8 & $\begin{array}{l}\text { Reverse Water } \\
\text { Osmosis }\end{array}$ & 2 & 4.5 & - & 0.80 & 380 \\
\hline 9 & Boat Crane & 1 & 3 & 0.80 & 0.80 & 380 \\
\hline 10 & Boom Crane & 1 & 105 & 0.80 & 0.80 & 380 \\
\hline 11 & $\begin{array}{l}\text { Stair Winch } \\
\text { Lier }\end{array}$ & 4 & 2.2 & 0.80 & 0.80 & 380 \\
\hline 12 & $\begin{array}{l}\text { Battery } \\
\text { Charger }\end{array}$ & 1 & 4.32 & - & 0.80 & 380 \\
\hline 13 & $\begin{array}{l}\text { Washing } \\
\text { Machine }\end{array}$ & 3 & 0.7 & 0.80 & 0.80 & 220 \\
\hline 14 & $\begin{array}{l}\text { Air Compressor } \\
\text { (Main Engine } \\
\text { Starter) }\end{array}$ & 2 & 21 & 0.80 & 0.81 & 380 \\
\hline 15 & $\begin{array}{l}\text { Air Compressor } \\
\text { (Diving Tube) }\end{array}$ & 1 & 3 & 0.80 & 0.80 & 380 \\
\hline 16 & $\begin{array}{l}\text { Air Compressor } \\
\text { (Auxiliary) }\end{array}$ & 1 & 4 & 0.80 & 0.80 & 380 \\
\hline
\end{tabular}

\section{Peralatan Pemadam Kebakaran}

Tabel 4.15 Peralatan Pemadam Kebakaran

\begin{tabular}{|l|l|l|l|l|l|l|}
\hline \multirow{2}{*}{ No } & Description & Qty & \multicolumn{4}{|l|}{ Rating } \\
\cline { 4 - 7 } & & $\mathrm{kW}$ & eff & PF & Vs \\
\hline 1 & $\begin{array}{l}\text { Fire Fighting } \\
\text { Pump }\end{array}$ & 1 & 21 & 0.80 & 0.80 & 380 \\
\hline 2 & $\begin{array}{l}\text { Fire } \\
\text { Preventing } \\
\text { Pump }\end{array}$ & 1 & 10 & 0.80 & 0.80 & 380 \\
\hline 3 & $\begin{array}{l}\text { Smoke, } \\
\text { Flame and } \\
\text { Heat } \\
\text { Detector }\end{array}$ & 3 & 0.011 & - & - & 220 \\
\hline
\end{tabular}

\section{Peralatan Dapur}

Tabel 4.16 Peralatan Dapur

\begin{tabular}{|l|l|l|l|l|}
\hline \multirow{2}{*}{ No } & \multirow{2}{*}{ Description } & \multirow{2}{*}{ Qty } & \multicolumn{2}{|l|}{ Rating } \\
\cline { 4 - 5 } & & $\mathrm{kW}$ & $\mathrm{Vs}$ \\
\hline 1 & Frying Pan & 1 & 4.4 & 380 \\
\hline 2 & $\begin{array}{l}\text { Rice } \\
\text { Cooker }\end{array}$ & 2 & 4.4 & 380 \\
\hline 3 & Hot Plate & 1 & 19 & 380 \\
\hline
\end{tabular}

\subsection{Penentuan Kapasitas Generator Utama KRI Teluk Celukan Bawang 532}

Setelah dilakukan perhitungan tiaptiap beban, dapat diketahui daya semu (kVA) pada masing - masing kondisi operasi kapal. Dengan diketahuinya total daya beban maka dapat ditentukan jumlah dan kapasitas generator yang akan digunakan.

Untuk menghitung kapasitas generator perlu diketahui pula Diversity Factor $(F d)$. Dalam perhitungan ini diketahui $\mathrm{Fd}=0.7$ dalam kondisi sandar, $\mathrm{Fd}=0,7$ dalam kondisi persiapan berlayar, $\mathrm{Fd}=0.6$ dalam kondisi berlayar. Maka :

Kapasitas Generator Kondisi Sandar $=\mathrm{Fd}$ $x$ Total Beban

$$
\begin{aligned}
& =0.7 \times 248.29 \\
& =173.8 \mathrm{kVA}
\end{aligned}
$$

Kapasitas Generator Kondisi Persiapan Berlayar $=\mathrm{Fd} \times$ Total Beban

$$
\begin{aligned}
& =0.7 \times 778.03 \mathrm{kVA} \\
& =544.62 \mathrm{kVA}
\end{aligned}
$$

Kapasitas Generator Kondisi Berlayar

$$
\begin{aligned}
& =\mathrm{Fd} \times \text { Total Beban } \\
& =0.6 \times 692.53 \mathrm{kVA} \\
& =415.52 \mathrm{kVA}
\end{aligned}
$$


Oleh karena beban minimum pada kapal 173.8 kVA dan beban maksimum 544.62 kVA, jika beban maksimum adalah $80 \%$ kapasitas generator maka dibutuhkan generator yang berkapasitas 700 kVA.

Jadi sistem kelistrikan KRI Teluk Celukan Bawang 532 menggunakan 3 unit diesel generator dengan kapasitas sebesar 350 kVA, sedangkan diesel generator yang terpasang saat ini dengan jumlah 4 unit berkapasitas 338 kVA.

\subsection{Penentuan Kapasitas Baterei Suplai Listrik Sistem Navigasi dan Komunikasi KRI Teluk Celukan Bawang 532}

Tabel 4.17 Pemakaian arus listrik sistem navigasi dan komunikasi

\begin{tabular}{|c|c|c|c|c|}
\hline \multirow[b]{2}{*}{ No } & \multirow[b]{2}{*}{ Description } & \multicolumn{3}{|c|}{ Rating } \\
\hline & & Watt & $\begin{array}{l}\text { Vs } \\
\text { DC }\end{array}$ & Amp \\
\hline 1 & Gyro Compass & 1200 & 84 & 14,3 \\
\hline 2 & $\begin{array}{l}\text { Magnet } \\
\text { Compass }\end{array}$ & 65 & 24 & 2,7 \\
\hline 3 & Speed Log & 750 & 84 & 8,9 \\
\hline 4 & $\begin{array}{l}\text { General } \\
\text { Positioning } \\
\text { System }\end{array}$ & 100 & 24 & 4,2 \\
\hline 5 & $\begin{array}{l}\text { Navigation } \\
\text { Control Board }\end{array}$ & 1000 & 84 & 11,9 \\
\hline 6 & RFT Radar & 600 & 84 & 7,1 \\
\hline 7 & $\begin{array}{l}\text { HF - } \\
\text { Tranceiver \& } \\
\text { Receiver }\end{array}$ & 200 & 24 & 8,3 \\
\hline 8 & $\begin{array}{l}\text { VHF - } \\
\text { Tranceiver \& } \\
\text { Receiver }\end{array}$ & 300 & 24 & 12,5 \\
\hline
\end{tabular}

Oleh karena tegangan DC yang diperlukan sistem navigasi dan komunikasi terdiri dari tegangan $84 \mathrm{~V}$ dan $24 \mathrm{~V}$ maka kapasitas baterai ditentukan berdasarkan tegangan kerja.

\section{Tegangan kerja $84 \mathrm{~V}$}

Untuk mendapatkan tegangan $84 \mathrm{~V}$ maka diperlukan 7 unit baterei $12 \mathrm{~V}$ yang dirangkai secara seri. Total arus listrik pemakaian tegangan $84 \mathrm{~V}$ adalah $42.2 \mathrm{~A}$. Kapasitas baterei $=42.2 \mathrm{~A} \times 1$ jam

$$
=42.2 \mathrm{Ah}
$$

Jadi kapasitas baterei yang diperlukan untuk tegangan kerja $84 \mathrm{~V}$ adalah $50 \mathrm{Ah}$.

\section{Tegangan $24 \mathrm{~V}$}

Untuk mendapatkan tegangan $24 \mathrm{~V}$ maka diperlukan 2 unit baterei $12 \mathrm{~V}$ yang dirangkai secara seri. Total arus listrik pemakaian tegangan $24 \mathrm{~V}$ adalah $27.7 \mathrm{~A}$. Kapasitas baterei $=27.7 \mathrm{~A} \times 1$ jam

$$
=27.7 \mathrm{Ah}
$$

Jadi kapasitas baterei yang diperlukan untuk tegangan kerja $24 \mathrm{~V}$ adalah $50 \mathrm{Ah}$.

\subsection{Perhitungan Beban Vital KRI Teluk Celukan Bawang 532}

Total beban vital $/$ penting $=55 \mathrm{kVA}$

Maka diperlukan 1 unit diesel generator darurat dengan kapasitas 60 kVA. sedangkan diesel generator darurat yang saat ini terpasang memiliki kapasitas 62 kVA.

\section{KESIMPULAN}

Dari hasil studi sistem kelistrikan pada kapal perang TNI AL kelas Frosch KRI Teluk Celukan Bawang 532 dapat diambil kesimpulan sebagai berikut :

a. Sistem tenaga listrik pada kapal merupakan salah satu sistem tenaga yang digunakan untuk mengoperasikan kapal perang. Sistem tenaga pada kapal perang terdiri dari sistem tenaga penggerak kapal dan sistem tenaga listrik kapal.

b. Sistem tenaga listrik pada kapal terdiri dari sekurang-kurangnya 2 agregat yang terpisah dari mesin utama.

c. Sistem suplai tenaga listrik pada KRI Teluk Celukan Bawang 532 dengan total beban listrik saat kondisi sandar sebesar 255.39 kVA, persiapan berlayar $761.92 \mathrm{kVA}$, berlayar 428.77 kVA dan dengan memperhitungkan diversity factor pada tiap-tiap kondisi operasi kapal maka dalam perencanaan ini dibutuhkan 3 unit generator dengan kapasitas masingmasing sebesar 350 kVA. Sedangkan generator yang terpasang saat ini berjumlah 4 unit berkapasitas masing-masing sebesar $338 \mathrm{kVA}$.

d. Total beban vital pada KRI teluk Celukan Bawang 532 sebesar 55 kVA maka dalam perencanaan ini dibutuhkan 1 unit diesel generator 
darurat dengan kapasitas 60 kVA. Sedangkan kapasitas generator darurat yang saat ini terpasang adalah 62 kVA berjumlah 1 unit.

e. Kapasitas dan jumlah baterei suplai listrik sistem navigasi dan komunikasi adalah 7 unit baterei $12 \mathrm{~V}$ berkapasitas 50 Ah yang dirangkai secara seri untuk menghasilkan tegangan $84 \mathrm{~V}$ dan 2 unit baterei $12 \mathrm{~V}$ berkapasitas 50 Ah yang drangkai secara seri untuk menghasilkan tegangan $24 \mathrm{~V}$. Sedangkan kapasitas baterei yang saat ini terpasang adalah 100 Ah untuk menghasilkan tegangan $84 \mathrm{~V}$ dan $100 \mathrm{Ah}$ untuk menghasilkan tegangan $24 \mathrm{~V}$.

\section{REFERENSI}

1. Affandi, AN. (2010). Operasi Sistem Tenaga Listrik. Yogyakarta: Penerbit Gava Media.

2. Aswanto, Nun Isnan. (2009). Perancangan Instalasi Listrik Kapal. Makassar: Universitas Hasanudin

3. Biro Klasifikasi Indonesia. (2016). Rules For Electrical Installations (Vol. IV). Jakarta: Author
4. Novarianto. (2010). Analisa Karakteristik Kebutuhan Daya Pada Kapal Cargo Dalam Rangka Effisiensi Energi. Surabaya: Institut Teknologi Surabaya

5. Marsudi, Djiteng. (2006). Pembangkit Energi Listrik. Jakarta: Penerbit Erlangga

6. Marsudi, Djiteng. (2006). Operasi Sistem Tenaga Listrik. Yogyakarta: Penerbit Graha IImu.

7. Suardi. (2009). Desain Kapal IV. Makassar: Universitas Hasanuddin

8. Sunaryo. (2016, November 22,23,24). Personal Interview.

9. Suryatmo, F. (1994). Dasar-Dasar Teknik Listrik. Jakarta: Penerbit Bina Adiaksara

10. Sutiyono. 1986. Sistem Penyediaan Tenaga Listrik di PT SCTI. Jakarta: STT Kusuma Negara 